\title{
Heart transplantation results from the Department of Cardiology at Dubrava University Hospital
}

\author{
(OMario Udovičić*, \\ -Danijela Grizelj, \\ - Vanja Ivanović \\ Mihajlović, \\ CHrvoje Falak, \\ (DAna Jordan, \\ (1) lgor Rudež, \\ DDavor Barić, \\ DDaniel Unić, \\ ORobert Blažeković, \\ (1) Josip Varvodić, \\ DDubravka Jonjić, \\ BBoris Starčević
}

University Hospital Dubrava,

Zagreb, Croatia

\author{
KEYWORDS: heart failure, heart transplantation, prognosis. \\ CITATION: Cardiol Croat. 2021;16(1-2):33. | https://doi.org/10.15836/ccar2021.33
}

*ADDRESS FOR CORRESPONDENCE: Mario Udovičić, Klinička bolnica Dubrava, Av. Gojka Šuška 6, HR-10000 Zagreb, Croatia. / Phone: +385-98-477248 / E-mail: mario.udovicic@gmail.com

ORCID: Mario Udovičić, https://orcid.org/0000-0001-9912-2179 • Danijela Grizelj, https://orcid.org/0000-0002-8298-7974 Vanja Ivanović Mihajlović, https://orcid.org/0000-0001-6931-5404 • Hrvoje Falak, https://orcid.org/0000-0002-6502-683X Ana Jordan, https://orcid.org/0000-0001-5610-6259 • Igor Rudež, https://orcid.org/0000-0002-7735-6721 Davor Barić, https://orcid.org/0000-0001-5955-0275 • Daniel Unić, https://orcid.org/0000-0003-2740-4067 Robert Blažeković, https://orcid.org/0000-0001-7125-361X • Josip Varvodić, https://orcid.org/0000-0001-6602-699X Dubravka Jonjić, https://orcid.org/0000-0002-9644-9739 • Boris Starčević, https://orcid.org/0000-0002-3090-2772

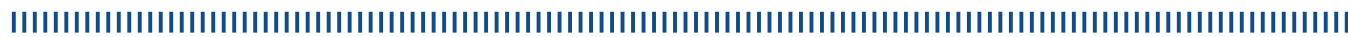

Heart transplantation (HTx) remains the gold standard and treatment of choice for advanced heart failure refractory to other methods $\mathrm{s}^{1,2}$. In this study we report a single center experience and outcomes of patients referred to HTx by the Department of Cardiology, University Hospital Dubrava (UHD). All patients underwent HTx at the Department of Cardiac and Transplantation Surgery UHD, and were subsequently referred for follow up in close collaboration of two departments. We retrospectively examined the outcomes from $108 \mathrm{HTx}$ recipients between 1995 and October 2020. The mean recipient age was 52.9 years, and $83.3 \%$ were male. Dilated cardiomyopathy was present in $56 \%$, ischemic in $37 \%$ and $7 \%$ were other causes. 26 recipients (24.1\%) were placed either on high urgent list of Eurotransplant or on national high urgent list. Survival was studied using Kaplan-Meier curves. Early in-hospital mortality was $10.2 \%$. The global survival rates at 1,5 , and 10 years are $85.2 \%, 77.5 \%$ and $62.0 \%$ respectively. The mean survival is 141.5 months ( $95 \%$ CI, 117.2-165.1). Including patients referred from other centers, there have been 208 HTx in UHD in total since 1995. Annual HTx number peaked in 2019 when 21 HTx were performed, while in 2020 due to the COVID-19 lockdown only 12 HTx have been done so far. Three HTx recipients have been diagnosed with COVID-19 by now, two of which required hospitalization and high flow oxygen therapy, but all eventually recovered. Post-HTx survival rates at 1, 5, and 10 years remain high in UHD, while the program is currently facing challenges due to COVID-19 pandemic.
RECEIVED:

December 6, 2020

ACCEPTED:

December 18, 2020

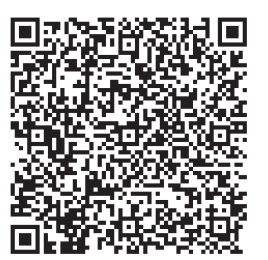

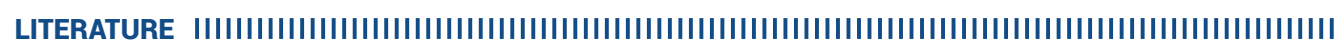

1. Mehra MR, Canter CE, Hannan MM, Semigran MJ, Uber PA, Baran DA, et al; International Society for Heart Lung Transplantation (ISHLT) Infectious Diseases, Pediatric and Heart Failure and Transplantation Councils. The 2016 International Society for Heart Lung Transplantation listing criteria for heart transplantation: A 10-year update. J Heart Lung Transplant. 2016 Jan;35(1):1-23. https://doi.org/10.1016/j.healun.2015.10.023

2. Crespo-Leiro MG, Metra M, Lund LH, Milicic D, Costanzo MR, Filippatos G, et al. Advanced heart failure: a position statement of the Heart Failure Association of the European Society of Cardiology. Eur J Heart Fail. 2018 Nov;20(11):1505-1535. https://doi.org/10.1002/ejhf.1236 